\title{
Conservatisme en het conceptual framework van de IASB
}

\section{Sigrid Vandemaele en Ellen Janssen}

SAMENVATTING Over de plaats van het voorzichtigheidsbeginsel binnen het Conceptual Framework (CF) is, in het kader van de voorstellen tot wijziging van het CF, veel discussie geweest, met name vanuit de $\mathrm{EU}$, en dit vanwege de wens om een zeker 'conservatisme' in financiële overzichten te behouden. In deze bijdrage wordt ingegaan op het concept 'accounting conservatisme' en wordt aandacht besteed aan de belangrijkste elementen binnen het CF die bijdragen aan conservatisme in financiële overzichten. Naast een behandeling van het voorzichtigheidsbeginsel wordt er vooral aandacht besteed aan de definitie van activa als bron van conservatisme.

RELEVANTIE VOOR DE PRAKTIJK De vraag is wat voor gevolgen de publicatie van het nieuwe Conceptual Framework zal hebben voor de dagelijkse verslaggevingspraktijk. Aangezien de definitie van activa nauwelijks wijzigt en, zoals Barker (2015) stelt, dit de belangrijkste bron van conservatisme is, verwachten we geen belangrijke wijziging in accounting conservatisme in de (nabije) toekomst.

\section{Inleiding}

Recente discussies binnen de accountingprofessie leren dat het CF (International Accounting Standards Board) nog steeds het onderwerp uitmaakt van controverse. Meer specifiek werd veel gezegd en geschreven rond het concept 'prudence', dat in een eerder voorstel van CF (2010) werd geschrapt maar recentelijk terug werd ingevoerd (ED: IASB, 2015). Velen bepleitten het behoud van het voorzichtigheidsbeginsel vanuit de wens een zeker conservatisme in financiële overzichten te behouden.

In deze bijdrage worden de belangrijke concepten onderliggend aan het debat, met name accounting conservatisme en het voorzichtigheidsbeginsel, besproken en wordt nagegaan wat de bijdrage is van verschillende inhoudelijke elementen van het $\mathrm{CF}$ voor het bereiken van accounting conservatisme, ervan uitgaand dat deze elementen leidend zijn bij de inrichting van een jaarrekening.
Het artikel kent de volgende opbouw. Allereerst wordt aandacht besteed aan het begrip 'conservatisme'. In paragraaf drie worden belangrijke inhoudelijke elementen van het CF in verband gebracht met conservatisme. Paragraaf vier bevat de slotbeschouwing.

\section{Accounting conservatisme: begrip en maat- staven}

De literatuur schuift een groot aantal definities van accounting conservatisme naar voor. Vooreerst zijn er de definities die verwijzen naar een benchmark en gebaseerd zijn op het verschil tussen de economische waarde en de boekwaarde. Volgens Roychowdhury en Watts (2007, p. 9) wordt de volgende definitie van accounting conservatisme veelvuldig gehanteerd in de empirische literatuur: "the difference between market value and reported book value, or the difference between change in market value and that in reported book value".

Barker (2015) geeft de volgende definitie: "Accounting is conservative if the economic value of an entity's equity exceeds its book value" (Barker, 2015, p. 516).

Ruch en Taylor (2015) stellen: "Accounting conservatisme can be defined as accounting policies or tendencies that result in the downward bias of accounting net asset value relative to economic net asset value" (Ruch \& Taylor, 2015, p. 20).

In bovenstaande definities verwijst economische waarde of marktwaarde naar de huidige waarde van verwachte cash flows die toebehoren aan aandeelhouders. Economische waarde is een schatting en het resultaat van het verdisconteren van geprojecteerde kasstromen. Boekwaarde verwijst naar de waarde waartegen deze activa opgevoerd worden in de balans. Volgens deze definities wordt conservatisme gedefinieerd in relatieve termen. Een uitkomst kan enkel als conservatief worden omschreven in vergelijking met een alternatieve uitkomst die niet conservatief of, met andere woorden, neutraal is. De benchmark is hier de economische waarde van het eigen vermogen ${ }^{1}$. Het hanteren van deze benchmark impliceert niet dat economische waarde als doelstelling/norm van de rapportage wordt gezien. Een verschil in economische waarde en boekwaarde zal zich voordoen telkens wanneer er een uitgestelde ver- 
werking is in de boekwaarde van een toename in economische waarde (Guay \& Verrecchia, 2006).

Het is duidelijk dat bovenstaande definities gebaseerd zijn op de balans, waarbij economische waarde de benchmark is voor conservatisme in boekwaarde. Een vaak gehanteerde maatstaf van conservatisme is de marktwaarde-boekwaarde-ratio (Market To Book of MTB), waarbij de marktwaarde van het eigen vermogen gerelateerd wordt tot de boekwaarde van het eigen vermogen. Een hogere MTB is een indicatie voor sterker conservatisme. De onderliggende assumptie is, dat in efficiënte financiële markten, de marktwaarde de economische waarde weergeeft.

Conservatisme zoals hierboven gedefinieerd is de uitkomst van accounting keuzes gemaakt binnen het bedrijf. Deze accounting praktijken kunnen a priori vastgelegd zijn, d.w.z. dat systematisch praktijken worden toegepast die leiden tot een (relatief) lage boekwaarde, zoals bijvoorbeeld het niet activeren van uitgaven voor onderzoek en ontwikkeling (R\&D). In dit geval spreekt men van a priori of niet-conditioneel conservatisme. Het kan daarnaast het gevolg zijn van het toepassen van accounting praktijken waarbij het netto-actief gereduceerd wordt ingeval van slecht nieuws (b.v. toepassen van de 'lower of cost or market'-regel) maar niet naar boven wordt herzien ingeval van goed nieuws (Basu, 2005; Ryan, 2006). In dit geval spreekt men van ex post of conditioneel conservatisme, d.w.z. het voorwaardelijk toepassen van conservatisme.

De vraag of conservatisme, een uitkomst van accounting keuzes, wenselijk is hangt af van de drijfveer onderliggend aan de keuzes. Indien conservatisme het resultaat is van een opzettelijke onderschatting van economische winsten (b.v. vanuit belastingmotieven) zodat de boekwaarde van het eigen vermogen kunstmatig laag is, gaat het over een vorm van conservatisme die vanuit het oogpunt van bruikbaarheid van financiële overzichten voor stakeholders van het bedrijf niet wenselijk is. Conservatisme daarentegen is wenselijk wanneer deze het gevolg is van een voorzichtige benadering van onzekerheid die ertoe leidt dat de verwerking van verwachte economische winst in financiële overzichten wordt uitgesteld totdat deze zekerder en meer verifieerbaar wordt. Algemeen wordt in de literatuur aangenomen dat een vraag bestaat naar deze vorm van conservatisme vanuit een 'contracting'-perspectief (Basu, 1997; Watts, 2006). Volgens deze visie is conservatisme een efficiënt mechanisme in het onderhandelen van financiële contracten, in het bijzonder met (potentiële) schuldeisers. Watts (2006) bijvoorbeeld verwijst naar het vermijden van te hoge dividenduitkeringen aan aandeelhouders ter bescherming van schuldeisers als een belangrijk 'contracting'-motief van conservatisme.

Een tweede reeks definities van conservatisme verwijst expliciet naar de asymmetrische behandeling van win- sten en verliezen als oorzaak van conservatisme. In tegenstelling tot de voorgaande, duiden deze definities het begrip conservatisme zonder verwijzing naar een benchmark.

Basu (1997, p. 4) omschrijft conservatisme als volgt: "I interpret conservatism as capturing accountants' tendency to require a higher degree of verificaton for recognising good news than bad news in the financial statements".

In zijn duiding van het begrip verwijst Watts (2006, p. 52) naar "a higher standard of verifiability required for recognition of gains than for losses".

Guay en Verrechia (2006, p. 150) omschrijven conservatisme als "more timely recognition of losses than gains resulting from asymmetric costs and benefits of reporting verifiable information by manager and/or firms".

De maatstaven van conservatisme gebaseerd op deze definities meten asymmetrische tijdigheid (of de gevolgen ervan) waarnaar de definitie van Guay en Verrechia (2006) verwijst en die het resultaat is van een asymmetrische toepassing van verwerkingscriteria voor verwachte winst versus verwacht verlies. In tegenstelling tot de MTB-maatstaf, die op de balans gebaseerd is, zijn deze maatstaven van asymmetrische tijdigheid gebaseerd op winstgegevens.

Asymmetrische tijdigheid wordt vaak gemeten via de reactiecoëfficiënt van de winst (Basu, 1997). Hierbij wordt nagegaan of de mate waarin nieuws in een gegeven periode wordt weerspiegeld in de bedrijfswinst (over diezelfde periode) afhankelijk is van het type nieuws, d.w.z. goed of slecht nieuws (zie kader 1). Gegeven dat het aandelenrendement de informatie weerspiegelt die de markt ontvangt van een veelheid van bronnen, gebruikt Basu (1997) dit als een proxy voor nieuws. Basu vindt slecht nieuws (negatief aandelenrendement) in grotere mate weerspiegeld in huidige winsten dan goed nieuws (positief aandelenrendement) en concludeert dat er aanwijzingen zijn voor 'asymmetrische tijdigheid'.

\section{Kader 1: het model van Basu (1997)}

\footnotetext{
De regressievergelijking die de reactie van winst op rendement meet op basis van het Basu-model (Basu, 1997) luidt als volgt: 
Kader 2: het model van Basu (1997), dat seriële afhankelijkheid toetst

Het model van Basu (1997) dat seriële afhankelijkheid toetst, is als volgt:

$\Delta \mathrm{NI}_{\mathrm{t}}=\mathrm{a}+\mathrm{b} \Delta \mathrm{NI}_{\mathrm{t}-1}+\mathrm{cD} \Delta \mathrm{NI}_{\mathrm{t}-1}+\mathrm{dD} \Delta \mathrm{NI}_{\mathrm{t}-1}{ }^{*} \Delta \mathrm{NI}_{\mathrm{t}-1}+\mathrm{e}_{\mathrm{t}}$

waarbij $\Delta \mathrm{NIt}\left(\Delta \mathrm{NI}_{\mathrm{t}-1}\right)$ de winstwijziging is in huidige (vorige) periode in vergelijking met de periode voordien, $\mathrm{D} \Delta \mathrm{NI}_{\mathrm{t}-1}$ een dummy variabele met waarde 1 indien $\Delta \mathrm{NI}_{\mathrm{t}}$. ${ }_{1}<1$ (en nul in het andere geval). De coëfficiënt d meet het verschil in seriële afhankelijkheid ingeval van een negatieve winstwijziging in huidige periode ten opzichte van een positieve winstwijziging. Een negatieve waarde van $d$ wijst op een lagere persistentie van winsten ingeval van slecht nieuws in vergelijking met goed nieuws ten gevolge van een meer tijdige verwerking van economische verliezen in vergelijking met economische winsten.
Basu (1997) stelt een tweede manier voor om asymmetrische tijdigheid te onderzoeken, met name via de studie van de persistentie van winstwijzigingen. De predictie is dat conservatisme resulteert in een lagere persistentie van winsten in periodes van slecht nieuws vergeleken met periodes van goed nieuws. Om deze predictie te toetsen, ontwikkelt Basu een model die de seriële afhankelijkheid (serial dependence) van winsten toetst (zie kader 2). Omdat dit model niet gebaseerd is op prijsgegevens (rendementen) kan het ook worden toegepast op private bedrijven.

De voornaamste beperking van Basu's model van seriele afhankelijkheid is dat het geen onderscheid maakt tussen verschillende componenten van winst (b.v. toevallige fouten in accruals of bepaalde vormen van winst management) die eenmalig of voorbijgaand van aard zijn en dus eveneens leiden tot seriële afhankelijkheid van winsten. Om aan deze tekortkoming tegemoet te komen, stellen Ball en Shivakumar (2005) een model voor gebaseerd op accruals. Het model steunt op het inzicht dat accruals tot doel hebben het tijdig verwerken van economische winsten of verliezen (zie kader 3). Omdat kasstromen van een duurzaam actief (zoals een productiecapaciteit) positief gecorreleerd zijn in de tijd, d.w.z. persistent zijn, zal dit leiden tot een positieve correlatie tussen accruals en gelijktijdige kasstromen. Immers, een wijziging in de huidige kasstroom is positief gecorreleerd met een huidige herziening van de verwachte toekomstige kasstromen (accrual). Ball en Shivakumar (2005) voorspellen dat deze positieve associatie asymmetrisch zal zijn. Ingeval economische verliezen tijdiger worden verwerkt dan economische winsten (via accruals), zal de positieve associatie tussen accruals en huidige kasstromen immers hoger zijn ingeval van economische verliezen.

Tot besluit kunnen we algemeen, d.w.z. onafhankelijk van drijfveren of oorzaken en onafhankelijk van onderliggende accountingpraktijken (a priori accounting keuzes versus accounting reacties op nieuws), stellen dat conservatisme zich uit in een verschil tussen boekwaarde en economische waarde van het eigen vermogen, waarbij deze laatste de eerste overstijgt. De MTB is in diezelfde zin een allesomvattende maatstaf van conservatisme omdat deze het cumulatieve effect meet, op balansdatum, van verwerking van winsten en verliezen in het verleden. Dit in tegenstelling tot bijvoorbeeld de Basu-maatstaf van conservatisme (reactiecoefficiënt) die gebruik maakt van een één-periode-rendement en daarom de reactie van bedrijfswinst op nieuws enkel in die ene periode meet. Deze één-periode-maatstaf is dus geen maatstaf van geaggregeerd conservatisme, in tegenstelling tot de MTB die niet enkel beïnvloed wordt door de reactie van winst op het rendement over één periode, maar door de cumulatieve reactie van winst op rendementen over alle voorgaande perioden.

\section{Conceptual Framework en conservatisme}

\subsection{Prudence in het conceptual framework en relatie tot con- servatisme}

Recent kwam een debat op gang over het concept 'prudence' naar aanleiding van de gewijzigde plaats die de IASB aan 'voorzichtigheid' toekent bij de herziening van het Conceptual Framework (CF) (zie Exposure Draft (ED; IASB, 2015). In 2010, werd het voorzichtigheidsbeginsel geschrapt in het CF om later, in 2014, terug ingevoerd te worden, zij het in geherformuleerde vorm. De herinvoering is gebeurd als reactie op een uiting van een duidelijke vraag naar voorzichtigheid van stakeholders.

De vraag naar prudence die geuit werd naar aanleiding van het schrappen van het beginsel in het voorstel CF (ED) kan gezien worden als een vraag naar een vorm van conservatisme, met name deze die het gevolg is van een asymmetrische behandeling van winst versus verlies ten gevolge van een voorzichtige houding ten opzichte van onzekerheid. Het hoeft geen betoog dat sta-

\section{Kader 3: het model van Ball en Shivakumar (2005)}

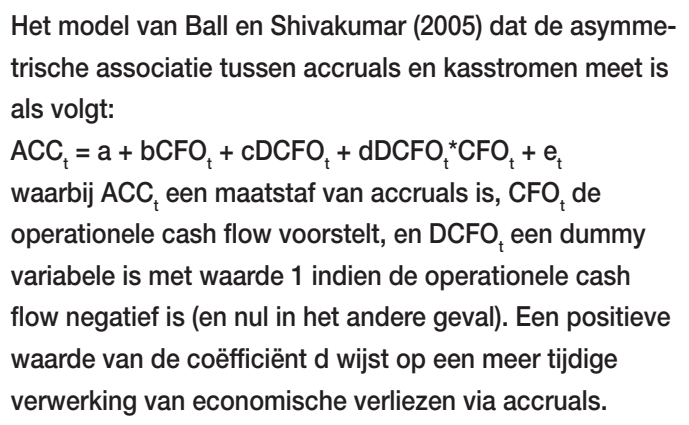
trische associatie tussen accruals en kasstromen meet is als volgt:

$\mathrm{ACC}_{\mathrm{t}}=\mathrm{a}+\mathrm{bCFO}_{\mathrm{t}}+\mathrm{cDCFO}_{\mathrm{t}}+\mathrm{dDCFO}_{\mathrm{t}} \mathrm{CCFO}_{\mathrm{t}}+\mathrm{e}_{\mathrm{t}}$ waarbij $A_{C C}$ een maatstaf van accruals is, $\mathrm{CFO}_{t}$ de operationele cash flow voorstelt, en $\mathrm{DCFO}_{t}$ een dummy variabele is met waarde 1 indien de operationele cash flow negatief is (en nul in het andere geval). Een positieve waarde van de coëfficiënt $d$ wijst op een meer tijdige verwerking van economische verliezen via accruals. 
keholders niet gebaat zijn bij conservatisme ingegeven door opzettelijke onderschatting van economische winsten. ${ }^{2}$ De vraag is of met opname van het (gewijzigd) voorzichtigheidsprincipe in het CF deze vraag 'adequaat' beantwoord wordt.

Binnen de huidige versie van het CF (IASC, 1989) is 'voorzichtigheid' een kenmerk van 'betrouwbaarheid' (reliability) en betekent voorzichtigheid het toepassen van een zekere mate van behoedzaamheid (degree of caution) in de oordeelsvorming wanneer schattingen worden gemaakt onder onzekerheid, zodat activa of winsten niet overschat worden en/of schulden of kosten niet onderschat. Terwijl bovenstaande definitie waarschuwt tegen overmatig optimisme, stelt het IASC (1989) dat het toepassen van voorzichtigheid niet mag leiden tot het creëren van verborgen reserves (hidden reserves) of overdreven voorzieningen (excessive provisions). Met deze aanvulling wordt het belang van neutraliteit in financiële overzichten onderstreept. Met neutraliteit wordt de afwezigheid van vooringenomenheid ('bias') bedoeld.

Barker (2015) sluit niet uit dat in het huidige CF een mogelijkheid gelezen wordt voor een toepassing van asymmetrische verificatiestandaarden op verwachte winst versus verlies vanuit een voorzichtige houding. Een dergelijke behandeling van winst/verlies leidt echter tot een 'bias' die niet verenigbaar is met neutraliteit. In dit geval moeten we besluiten dat het CF niet intern consistent is: immers voorzichtigheid en neutraliteit zijn niet verenigbaar. Indien daarentegen de mogelijkheid van interne inconsistentie binnen het CF uitgesloten wordt, dan moet voorzichtigheid geïnterpreteerd worden als een houding die een optimistische bias bij de opstellers van de jaarrekening moet 'neutraliseren'.

Binnen de exposure draft van het CF (IASB, 2015) werd het voorzichtigheidsbeginsel na verwijdering ervan in een eerder voorstel, terug ingevoerd onder 'getrouwe weergave' (kwalitatief kenmerk van nuttige informatie). De nieuwe formulering (ED: IASB, 2015) stelt dat het toepassen van voorzichtigheid overeenstemt met neutraliteit en niet mag leiden tot een over- of onderschatting van activa, passiva, opbrengsten of kosten. De nieuwe formulering benadrukt (nog meer dan vroeger) dat voorzichtigheid moet leiden tot neutraliteit, en in die zin dus een optimistische 'bias' neutraliseert. Het vooropstellen van neutraliteit brengt met zich mee dat er geen ruimte is voor asymmetrische verificatiestandaarden toegepast op winsten in vergelijking met verliezen. Ter Hoeven (2016, p. 11) stelt dat "voorzichtigheid als een vanuit de regelgeving geïndiceerde 'contra-bias' kan worden beschouwd”. Neutraliteit wordt ondersteund door het toepassen van voorzichtigheid. Op basis van een dergelijke lezing van de nieuwe versie van het CF kan worden gesteld dat het herinvoeren van het voorzichtigheidsprincipe niet tegemoet komt aan de vraag naar enig conservatisme in de financiële overzichten. Dit blijkt ook uit het feit dat het debat rond dit beginsel niet gesloten is. Zo stelt Hoogendoorn (2016) dat het verschaffen van een getrouw beeld kan nopen tot 'asymmetric prudence'. Met 'asymmetric prudence' wordt bedoeld het feit dat ongerealiseerde winsten en verliezen anders worden behandeld en dat aan activering zwaardere eisen worden gesteld dan aan passivering (Ter Hoeven, 2016). Voorzichtigheid in die zin is niet steeds verenigbaar met neutraliteit. De 'European Financial Reporting Advisory Group' (EFRAG, 2015) pleit voor het expliciet onderkennen van de trade-off tussen deze twee beginselen (neutraliteit en voorzichtigheid) in het CF. Hoogendoorn (2016) geeft eveneens aan, en vertaalt daarmee het standpunt van de EU in deze, dat de huidige formulering van voorzichtigheid in het CF beperkt is aangezien een aantal IFRS-standaarden de benadering van 'asymmetric prudence' feitelijk hanteert (en de feitelijk toegepaste voorzichtigheid binnen IFRS dus groter is). EFRAG (2015) betreurt dat de weergave van voorzichtigheid in het CF (ED: IASB, 2015) hierbij niet aansluit.

Hoogervorst (2012) daarentegen stelt dat een explicitering van het voorzichtigheidsbeginsel in het CF niet nodig is om tot 'voorzichtige' of 'conservatieve' schattingen in de financiële overzichten te komen, juist omdat standaarden (voldoende) doordrongen zijn van het voorzichtigheidsbeginsel. ${ }^{3}$

Ook Barker (2015) vindt de discussie rond het voorzichtigheidsbeginsel als basis voor conservatisme in de financiële overzichten niet relevant. Hij argumenteert dat andere elementen in het CF, en met name de definitie van een 'actief', een inherent conservatisme in zich dragen en daarbij tegemoetkomen aan de vraag van de stakeholders naar voorzichtigheid. Het standpunt van Barker wordt uitgewerkt in volgende paragraaf.

\subsection{Definitie van actief en conservatisme}

Barker (2015) stelt dat accounting niet een systeem is van neutrale meting van economische waarde, maar dat conservatisme een intrinsieke eigenschap is van het accountingsysteem.

In dit verband maakt Barker een onderscheid tussen 'framework neutrality' en 'economic neutrality'. 'Economic neutrality' verwijst naar een methode van accounting die resulteert in gelijkheid tussen boekwaarde en economische waarde; 'framework neutrality' verwijst naar een methode van accounting die een consistente toepassing is van de concepten en definities in het conceptueel raamwerk. Barker stelt dat 'framework neutrality' leidt tot asymmetrische verwerking van economische winsten en verliezen en dus tot conservatisme in de zin dat de boekwaarde lager zal zijn dan de economische waarde. 'Framework neutrality' leidt dus 
tot afwezigheid van 'economic neutrality'. Hij wijst erop dat dit resultaat zich voordoet in afwezigheid van een expliciete bias in de toepassing van verificatiecriteria voor winst versus verlies.

Opname in de balans vereist dat aan de definitie van een actief wordt voldaan. Centraal in de argumentatie van Barker staat de definitie van een actief, die is weergegeven in het CF (ED: IASB, 2015) als volgt: "An asset is a present economic resource controlled by the entity as a result of past events. An economic resource is a right that has the potential to produce economic benefits".

De huidige definitie (IASC, 1989) luidt als volgt: "An asset is a resource controlled by the entity as a result of past events and from which economic benefits are expected to flow to the entity". Naast het feit dat in de nieuwe definitie niet meer gesteld wordt dat voordelen verwacht moeten zijn - volgens de nieuwe definitie moet het bedrijfsmiddel de potentie hebben om voordelen te genereren - ligt het belangrijkste verschil tussen de bestaande en de nieuw voorgestelde definitie hierin dat deze laatste 'economic resource' afzonderlijk definieert als een recht. Zodoende wordt de activering beoogd van het eigendomsrecht dat het bedrijf in staat stelt het actief in te zetten teneinde economische voordelen te genereren.

Barker (2015) argumenteert dat (alleen al) het consistent toepassen van de definitie van een 'actief' leidt tot accounting conservatisme in de zin dat de boekwaarde lager zal zijn dan economische waarde ${ }^{4}$. Anders gesteld, het is impliciet in de definitie en betekenis van activa dat accounting conservatief (of voorzichtig) is. Bovenstaande definitie van actief is opgebouwd rond drie concepten: economische voordelen (economic benefits), economische middelen (economic resources) en controle (control).

Gebaseerd op deze drie concepten, geeft Barker (2015) de volgende definitie van de boekwaarde van een actief: "The book value of an asset is the value attributed to control over legal, or de facto, property rights with respect to economic benefits" (Barker, 2015, p. 524).

Om tot activering over te gaan, moeten volgens Barker (2015) de volgende twee belangrijke vragen worden beantwoord:

1. Bestaan er (wettelijke of de facto) eigendomsrechten die de entiteit toelaten zich de economische voordelen toe te eigenen? (d.w.z. bestaat een actief?).

2. Kan waarde worden gemeten en toegewezen aan deze eigendomsrechten? (d.w.z. kan de waarde van het actief worden gemeten?).

Deze vragen zijn fundamenteel met het oog op het begrip van de mate waarin economische waarde overeenkomt met waarde weergegeven in de balans, d.w.z. de mate van accounting conservatisme. Deze vragen worden hieronder achtereenvolgens behandeld.

1. Bestaan er eigendomsrechten die de entiteit toela- ten zich de economische voordelen toe te eigenen? Barker (2015) stipt aan dat de mogelijkheid van toe-eigening een fundamentele voorwaarde is voor het bestaan van een economisch voordeel (waarde kan worden gecapteerd). Het bestaan van economische voordelen is gebaseerd op schaarsheid en de mogelijkheid anderen uit te sluiten van de voordelen (zeggenschap). Indien een onderneming beslist om bepaalde kennis wettelijk te beschermen via copyrights en geheimhoudingsplicht, dan is er sprake van zeggenschap. Uitgaven voor training zijn bijvoorbeeld uitgesloten van activering omwille van een gebrek aan zeggenschap. Een ondernemer kan niet beletten dat een goed getrainde werknemer vertrekt.

In het kader van accounting zijn economische voordelen enkel relevant voor zover zij toegeëigend werden onder de vorm van bedrijfsmiddelen. Indien er economische voordelen bestaan die niet terug te leiden zijn tot huidige/bestaande bedrijfsmiddelen, vallen ze buiten het bereik van accounting (Barker, 2015). Dit aspect geeft onvermijdelijk aanleiding tot accounting conservatisme. Dit zal het geval zijn telkens wanneer er toekomstige economische voordelen zijn die men verwacht in de toekomst te kunnen toe-eigenen en deze weerspiegeld zijn in de economische waarde van een entiteit (d.w.z. in de aandelenprijs) maar nog niet werden toegeëigend in de vorm van bedrijfsmiddelen (en dus niet verschijnen op de balans). Het meest voor de hand liggend voorbeeld van dergelijke verwachte voordelen die niet terug te leiden zijn naar bedrijfsmiddelen zijn verwachte verkopen van een product, gebaseerd op een geschat marktaandeel, waarvoor nog geen verkoopcontracten werden gesloten ${ }^{5}$. We kunnen dus stellen dat in zoverre dat de economische waarde bestaat uit verwachte economische voordelen die nog niet werden toegeëigend accounting-conservatief zal zijn.

Naast voordelen die [a priori] bestaan en kunnen worden toegeëigend door het bedrijf, zoals verwachte verkopen, zijn voordelen vaak een direct gevolg van uitgaven gemaakt door de entiteit (Barker, 2015). Terwijl uitgaven op zich niet waardevol zijn, omdat waarde een functie is van inkomende kasstromen, is er in dit geval een onvermijdelijke relatie tussen uitgaven en het vermogen kasstromen te genereren.

Barker volgend, illustreren we de rol van uitgaven bij de totstandkoming van bedrijfsmiddelen aan de hand van 'voorraden'. De auteur wijst erop dat het door de IASB gehanteerde eigendomsrecht het economische eigendomsrecht is, dat ruimer is dan het wettelijke eigendomsrecht. Het economische eigendomsrecht verwijst naar het vermogen economische voordelen te genieten. Een entiteit kan bijvoorbeeld de economische voordelen genieten van aanwezige knowhow, ook zonder bescherming via wettelijke eigendomsrechten. De knowhow kan de entiteit immers in staat stellen exclusief (d.w.z. met uitsluiting van anderen) economische 
waarde toe te eigenen. Het ruimere begrip van eigendomsrecht brengt met zich mee de vraag waarop dit recht betrekking heeft. Barker (2015) stelt dat, ingeval van voorraden, het economisch eigendomsrecht betrekking heeft op de verwachte besparing ten gevolge van het feit dat de voorraad reeds werd aangeschaft: indien de entiteit in staat is de voorraad te verkopen op een toekomstig moment, dan is de netto-cashflow op dat moment groter ingeval de voorraad reeds in bezit is vergeleken met de situatie waarbij de voorraad nog moet worden aangekocht; het verschil in nettocashflow is de aanschafkosten van de voorraad. Het economische eigendomsrecht betreft dus niet de economische voordelen voortkomend uit de verkoop van de voorraad tegen een bepaalde prijs: immers, de entiteit heeft niet het recht om te eisen dat een potentiële klant de voorraad koopt, en heeft daarom niet het recht op de economische voordelen uit de verkoop. ${ }^{6}$ Met andere woorden, het recht ('resource') betreft de besparing (van aanschaffingskosten), niet het verwachte voordeel ten gevolge van de verkoop van de voorraad. Of, anders gesteld, de afdwingbare claim van de entiteit op iets waardevols betreft de kosten van de input, niet de waarde van de output. Het gevolg is dat accounting van voorraden conservatief zal zijn.

Een analoog argument geldt voor vaste activa: een economische middel (actief) bestaat in zoverre bedragen werden gespendeerd die men verwacht te kunnen terugverdienen en in zoverre deze uitgaven onvermijdbaar zijn/waren (met het oog op het verwerven van de opbrengsten) (Barker, 2015). In zoverre dat deze activa waarde-creërende investeringen betreffen, waarbij verwachte inkomsten hoger liggen dan huidige en verwachte kosten, zal accounting conservatief zijn. Hoewel dit geldt voor zowel materiële als immateriële activa, is er een belangrijk verschil tussen deze activa wat meetbaarheid betreft. Dit aspect wordt in volgende paragraaf behandeld.

2. Kan waarde worden gemeten en toegewezen aan eigendomsrechten?

Met betrekking tot meetbaarheid, zijn er twee moeilijkheden die kunnen bijdragen tot accounting conservatisme (Barker, 2015). Deze doen zich in sterkere mate voor bij immateriële activa in vergelijking met materiele activa. Ten eerste kan het onduidelijk zijn of kosten kunnen worden terugverdiend, met andere woorden of ze werkelijk economische voordelen vertegenwoordigen voor het bedrijf. Een mogelijk voorbeeld betreft publiciteitskosten. Door de moeilijkheid op een betrouwbare manier te meten of en in welke mate deze kosten effectief zijn, ligt het niet voor de hand dat dergelijke kosten waarde genereren. Ten tweede is het soms moeilijk kosten te observeren en/of het actief te identificeren. Een mogelijk voorbeeld betreft de waarde van een merknaam. Kosten voor de uitbouw van een merknaam zijn vaak moeilijk te observeren omdat ze verspreid zijn over verschillende bedrijfsactiviteiten en zelfs vaak het bijproduct zijn van uitgaven gedaan voor een ander expliciet doel. De moeilijkheid de kosten te observeren brengt met zich mee het probleem van identificeerbaarheid van het resulterende bedrijfsmiddel (actief). ${ }^{7}$

We kunnen stellen dat immateriële activa niet wezenlijk verschillen van tastbare activa in dat immateriële activa evengoed een bron van kostenbesparingen zijn. Doch, er is een verschil tussen beide categorieën van activa met betrekking tot meetbaarheid. Het gevolg is een groter conservatisme met betrekking tot immateriële activa.

\subsection{Passiva en conservatisme}

Bovenstaande discussie heeft enkel betrekking op activa. Een analoge analyse kan worden toegepast op passiva. Hierbij dient opgemerkt te worden dat passiva verondersteld worden beter meetbaar te zijn dan activa (Barker \& McGeachin, 2015). Terwijl uitdagingen met betrekking tot meetbaarheid mogelijks resulteren in het conservatief rapporteren van passiva, zijn deze waarschijnlijk een veel grotere bron van conservatisme in het geval van activa, waar een boekwaarde van nul vaak het antwoord is op de uitdaging van meetbaarheid. Dat passiva gemakkelijker meetbaar zijn dan activa heeft te maken met het feit dat passiva geassocieerd worden met direct toewijsbare economische voordelen, zij het voordelen die wegvloeien uit de onderneming.

\subsection{Verwerkingscriteria en conservatisme}

Volledigheidshalve gaan we nog kort in op de (wijziging in) verwerkingscriteria binnen het CF (hoofdstuk 5, ED: IASB, 2015) en hun implicaties voor conservatisme.

In plaats van de twee criteria in het huidige $C F$, waarschijnlijkheid (van in/uitstroom van economische voordelen) en betrouwbaarheid van waardering, vermeldt het CF (ED: IASB, 2015) de drie volgende criteria: relevantie, betrouwbare weergave en cost/benefit. De IASB stelt voor waarschijnlijkheid te schrappen als criterium. Bij het (nieuwe) criterium 'relevantie' wordt het element 'waarderingsonzekerheid' toegevoegd. Hiermee geeft de IASB aan open te staan voor de mogelijkheid (omstandigheid) dat de waarderingsonzekerheid zo hoog is dat waardering niet meer tot relevante informatie leidt. In aanwezigheid van hoge waarderingsonzekerheid is er dus een afweging (tradeoff) te maken tussen de voordelen van opname in de balans en het nadeel hiervan in de vorm van gebrek aan relevantie.

In zoverre het waarschijnlijkheidscriterium meer een drempel vormt voor de verwerking van een actief dan voor de verwerking van een passief, kan het terugdringen van dit criterium leiden tot relatief meer activering 
en bijgevolg minder conservatisme. Daarentegen vormt het element 'waarderingsonzekerheid' mogelijk eerder een nieuwe drempel voor activering dan voor het verwerken van een passief, wat dan weer conservatisme in de hand kan werken.

\subsection{Waarderingsgrondslag en conservatisme}

In het nieuwe voorstel van CF heeft de waarderingsgrondslag 'fair value' zijn plaats gevonden. Ter Hoeven (2016) stelt dat dit meer dan terecht is maar feitelijk te laat, daar het CF enkel erkent wat aan ruimte hieromtrent reeds bestond binnen de IFRS. Ook Cairns (2006) kenmerkt de IFRS als 'fair value based standards'.

\section{Besluit}

In deze bijdrage wordt stilgestaan bij het concept 'conservatisme' in de literatuur en wordt de link gelegd met het voorzichtigheidsbeginsel in het CF. Conservatisme duidt op een verschil tussen economische waarde (of marktwaarde) en boekwaarde en zal ontstaan telkens wanneer er een uitgestelde verwerking is in boekwaarde van een toename in economische waarde (Guay $\&$ Verrecchia, 2006). We identificeren de marktwaardeboekwaarde-ratio, die de verhouding weergeeft tussen marktwaarde en boekwaarde, als een allesomvattende maatstaf van conservatisme omdat deze het cumulatieve effect meet, op balansdatum, van de verwerking van winsten en verliezen in het verleden.

De vraag naar het behoud van het voorzichtigheidsbeginsel die geuit werd naar aanleiding van het schrappen van het beginsel in het voorstel CF (ED: IASB, 2015) interpreteren we als een vraag naar een bepaalde vorm van conservatisme, met name deze die het gevolg is van een asymmetrische behandeling van win- sten en verliezen ten gevolge van een voorzichtige houding ten opzichte van onzekerheid.

De opname van een geherformuleerd voorzichtigheidsbeginsel in de exposure draft van het CF (IASB, 2015) is geen afdoend antwoord op deze vraag. Immers, gezien de door het CF vooropgestelde neutraliteit, kan voorzichtigheid enkel worden geïnterpreteerd als een houding die een optimistische bias bij de opstellers van de jaarrekening moet 'neutraliseren'.

Barker (2015) vindt de discussie rond het voorzichtigheidsbeginsel als basis voor conservatisme irrelevant en argumenteert dat het CF, los van het voorzichtigheidsbeginsel, voldoende ruimte biedt om tegemoet te komen aan de vraag van de stakeholders naar voorzichtigheid. Hij argumenteert dat andere elementen in het $\mathrm{CF}$, en met name de definitie van een 'actief', een inherent conservatisme in zich dragen. De neutrale toepassing van het CF op dit vlak impliceert een asymmetrische verwerking van winst en verlies en zal leiden tot de gewenste vorm van conservatisme. Wij zijn het eens met Barker (2015) dat accounting conservatisme zich zal uiten in financiële grootheden wanneer en zolang de definitie van actief zoals weergegeven in het CF consistent wordt toegepast.

Prof. dr. S. Vandemaele is Universitair Hoofddocent bij de Vakgroep Accountancy, Financiering en Governance, Universiteit Hasselt, België.

E. Janssen is master in de Toegepaste Economische Wetenschappen, Handelsingenieur en is doctoraatsbursaal aan de Faculteit Bedrijfseconomische Wetenschappen, Universiteit Hasselt, België.

\section{Noten}

Impliciet wordt verondersteld dat de benchmark niet beïnvloed wordt door verslaggevingskeuzes.

2. Hier wordt impliciet verwezen naar de mogelijke drijfveren van conservatisme zoals weergegeven in paragraaf 2.

3 Voorzichtigheid is bijvoorbeeld van toepassing wanneer voorraden worden geboekt tegen 'lower of cost or net realisable value'.

4 De argumentatie van Barker (2015) is gebaseerd op de nieuw voorgestelde definitie van actief. In zoverre deze definitie een ruimer activabegrip hanteert dan de oude (Ter Hoeven, 2016) geldt Barkers redenering a fortiori wanneer gebaseerd op de oude definitie.
Verkopen die wel hebben plaatsgevonden vinden we op de balans terug in de vorm van handelsvorderingen die kunnen worden gezien als een eigendomsrecht met betrekking tot onbetaalde bedragen en in de vorm van cash, hetgeen kan gezien worden als de realisatie van economische voordelen, de laatste stap in het toe-eigeningsproces van voordelen.

6. Hier ligt een belangrijk verschil met een actief waarvoor een liquide markt bestaat waarbij de houder van het actief op elk moment de mogelijkheid heeft het actief te verkopen tegen de geldende marktprijs. Bijvoorbeeld, in het geval het actief een financieel instrument betreft, meet de geldende marktprijs (en niet de aanschaf- fingskosten) de economische voordelen. z In tegenstelling tot immateriële activa zijn materiële activa tastbaar en scheidbaar. Deze beide karakteristieken dragen bij tot de identificeerbaarheid van een bedrijfsactief, alsook tot het claimen van eigendom. In die zin dragen beide criteria bij tot het vaststellen van het bestaan van een bedriffsactief.

8 In zoverre IFRS in grotere mate op 'fair value' gebaseerd zijn dan de Nederlandse GAAP, heeft de invoering van IFRS (2005) mogelijk geleid tot minder conservatisme in financiële overzichten over de voorbije jaren. 
- Ball, R., \& Shivakumar, L. (2005). Earnings quality in UK private firms: comparative loss recognition timeliness. Journal of Accounting and Economics, 39: 83-128.

- Barker, R. (2015). Conservatism, prudence and the IASB's conceptual framework. Accounting and Business Research, 45(4): 514538.

- Barker, R., \& McGeachin, A. (2015). An analysis of concepts and evidence on the question of whether IFRS should be conservative. Abacus, 51(2): 169-207.

- Basu, S. (1997). The conservatism principle and the asymmetric timeliness of earnings. Journal of Accounting and Economics, 24(1): 3-37.

- Basu, S. (2005). Discussion of "conditional and unconditional conservatism: concepts and modelling". Review of Accounting Studies, 10(2/3): 311-321.

- Branch, B., Sharma, A., Chawla, C., \& Tu, F. (2014). An updated model of price-to-book.
Journal of Applied Finance, 24(1): 73-93.

- Cairns, D. (2006). The use of fair value in

IFRS. Accounting in Europe, 3(1): 5-22.

- European Financial Reporting Advisory Group (EFRAG) (2015). Document for Public Consultation, Exposure Draft Framework for Financial Reporting.

- Guay, W., \& Verrecchia, R. (2006). Discussion of an economic framework for conservative accounting. Journal of Accounting and Economics, 42: 149-165,

- Hoeven, R.L. ter (2016). Exposure Draft Conceptual Framework: Enige beschouwingen naar aanleiding van een 'filling the gap'-exercitie. Maandblad voor Accountancy en Bedrijfseconomie, 90(1/2): 9-19.

- Hoogendoorn, M. (2016). Algemene beginselen en het Conceptual Framework. Maandblad voor Accountancy en Bedrifseconomie, 90(1/2): 20-29.

- Hoogervorst, H. (2012). The concept of prudence: dead or alive? FEE Conference on Cor- porate Reporting of the Future, Brussels.

- International Accounting Standards Committee (IASC) (1989). Framework for the Preparation and Presentation of Financial Statements, London.

- International Accounting Standards Board (IASB) (2015). Exposure Draft ED/2015/3. Conceptual Framework for Financial Reporting, London.

- Roychowdhury, S., \& Watts, R. (2007). Asymmetric timeliness of earnings, market-to-book and conservatism in financial reporting. Journal of Accounting and Economics, 44: 2-31.

- Ruch, G.W., \& Taylor, G. (2015). Accounting conservatism: A review of the literature. Journal of Accounting Literature, 34: 17-38.

- Ryan, S. (2006). Identifying conditional conservatism. European Accounting Review, 15(4): 511-525.

- Watts, R.L. (2006). What has the invisible hand achieved? Accounting and Business Research, 36(1): 51-61. 